\title{
The Effect of CSR on Company Reputation Using Intellectual Capital as a Mediating Variable
}

\author{
Yuniep Mujati Suaidah*, Omi Pramiana, Dwi Ermayanti Susilo, Hadi Sucipto, Rachyu Purbowati \\ Accounting Department \\ STIE PGRI Dewantara \\ East Java, Indonesia \\ *yunip.dewantara@gmail.com
}

\begin{abstract}
This research aimed to analyze the effect of corporate social responsibility in improving the company's reputation, both directly and through the company's intellectual capital. The population of this study were the annual reports of banking sector companies listed on the Indonesia Stock Exchange. The researcher used purposive sampling method in this study. The total of research samples were 123 annual financial reports. To analyze the data, the researchers used Partial Lease Square (PLS) with the PLS warp application. The research findings indicated that Corporate Social Responsibility Practice positively and significantly affected to Intellectual Capital, Corporate Social Responsibility Practice positively and significantly affected to the company's reputation, Intellectual Capital positively and significantly affected to the company's reputation, and intellectual capital can be a partial mediating variable (partial mediation) among the CSR influence and the company reputation.
\end{abstract}

Keywords-CSR, intellectual capital, company reputation, banking sector

\section{INTRODUCTION}

Reputation is how other parties view a company, a person, a committee, or an activity. Every company has a reputation. Every company has as much reputation as the number of people looking at it. Various company reputations come from potential customers, bankers, company staff, competitors, distributors, suppliers, trade associations and customer movements in the trade sector who have views on the company.

Several researchers identified the company's reputation as one of the most important intangible assets, which can influence stakeholders [1]. A good reputation is one of the assets that is responsible for the sustainability of the company's financial outcomes [2]. This strategic potential is due to its value creation ability, as well as its intangible character. This makes the company's reputation difficult for the company's competitors to imitate, thus enabling the company to achieve a superior position. In an effort to form and maintain a reputation, there are many ways that can be applied, one of which is by reporting the company's Corporate Social Responsibility or CSR activities.

Previous research on the effect of CSR on company reputation showed that CSR had a significant positive effect on company reputation [3-6]. Meanwhile, research conducted by Yoon et al. [7] showed that CSR had a negative effect on company reputation. This is because the company in carrying out CSR activities that are judged by stakeholders is done insincerely so that it offends stakeholders. Bartley [8] states that CSR has a significant negative effect on company reputation, because CSR activities are considered solely for the benefit of the company. The research results show that CSR activities have a significant negative effect on the company's reputation because the company is inconsistent in carrying out CSR activities. The results of the study Coop News [9] show that CSR has a negative effect on the company's reputation because CSR activities are deducted from employees' salaries.

CSR activities are considered to have a positive relationship with intellectual capital which consists of human, organizational and relational capital $[10,11]$. The dimension of human capital, CSR activities can improve employee welfare through training programs. Furthermore, CSR activities improve the relationship between companies and employees by increasing employee loyalty and motivation. The positive impact of CSR activities on the dimensions of organizational capital is related to corporate strategy and culture along with management processes. The dimension of rational capital consists of brand image, customers, suppliers and financial relationships, where CSR results in the acquisition of new clients, an increase in company reputation and an increase in investor attention and financial performance [12]

Several previous studies on the effect of CSR on company reputation have shown inconsistent results. Therefore, the researcher wanted to re-examine the effect of CSR on company reputation by using Intellectual Capital as the mediating variable.

This study aims to determine what are the factors that influence banking sector companies in improving the 
company's reputation in terms of social and intellectual capital responsibility costs.

CSR as a strategic approach that can improve the social, economic, cultural and environmental sustainability aspects that can facilitate economic growth. Companies that implement this approach provide satisfaction to stakeholders and the ability and advantages of intangible resources such as intellectual capital [13]. According to Marchyta et al, 2020 CSR activities can improve company relations with employees by increasing employee motivation and loyalty. The results show that CSR has a positive and significant effect on intellectual capital $[13,14]$.

\section{$\mathrm{H}_{1}$ : CSR has a positive effect on intellectual capital}

CSR activities can increase consumer confidence, increase brand equity among customers [15], increase employee motivation [16], increase organizational commitment among employees and reduce risk to the company's share price through effective communication between managers and investors [17]. So that CSR activities can provide a good assessment and confidence in the sustainability of the company from investors and other stakeholders. This means that CSR activities can improve a company's reputation. The results of Park [3] show that CSR has a significant positive effect on the Company's reputation, while Purva Grover et al. Whose research entitled Impact of Corporate Social Responsibility on Reputation Insight From Tweets on Sustainable Development Goals by CEOS shows that CSR has a significant positive effect on the company's reputation. [6] the results of CSR research have a significant positive effect on company reputation. Likewise, the research results González-Ramos et al., Y ang et al., Maden et al., and Šontaitė-Petkevičienè [4$6,18]$.

\section{$\mathrm{H}_{2}$ : CSR has an effect positive towards Reputation company}

Human Capital management is an important factor for longterm financial performance and can create value and reduce risk. so that human capital can affect the company's reputation by looking at the perspectives of employees, investors and other stakeholders such as regulators and the government as well as the community and NGOS (ICGN, 2015).Furthermore, research Olmedo-Cifuentes and Martínez-León [11] and Hannon [19] shows that human capital has a positive and significant effect on company reputation. Human resource has an indirect influence on the company's reputation through increasing employee competence, motivation and organization, identification and then employees interacting with external stakeholders to convey the company's reputation [20]. This shows that increasing intellectual capital can improve the company's reputation.

$\mathrm{H}_{3}$ : Intellectual Capital has a positive effect on Reputation company.

The results of Park [3] show that CSR has a significant positive effect on the Company's reputation, while Purva Grover et al. Whose research entitled Impact of Corporate Social Responsibility on Reputation Insight From Tweets on
Sustainable Development Goals By CEOS shows that CSR has a significant positive effect on the company's reputation. Maden et al. [6], the results of CSR research have a significant positive effect on company reputation. Likewise, the research results González-Ramos et al., Y ang et al., and Maden et al., Šontaitè-Petkevičienè [4-6,18].

Meanwhile, research results Gallardo-Vázquez et al. [13], and Marchyta and Semuel [14], show that CSR has a positive and significant effect on intellectual capital. Furthermore, research Olmedo-Cifuentes and Martínez-León [11] and Hannon [19], shows that human capital has a positive and significant effect on company reputation. Human resource has an indirect influence on the company's reputation through increasing employee competence, motivation and organization, identification and then employees interacting with external stakeholders to convey the company's reputation [20]. This shows that increasing intellectual capital can improve the company's reputation. According to RBT and KBV, intellectual capital meets the criteria as a unique resource to create added value. This value added is in the form of better performance in the company. So that intellectual capital makes CSR activities more value-added so that it can increase the company's hassle.

$\mathrm{H}_{4}$ : Intellectual Capital mediates the relationship between CSR and the company's reputation.

The conceptual framework show in figure 1.

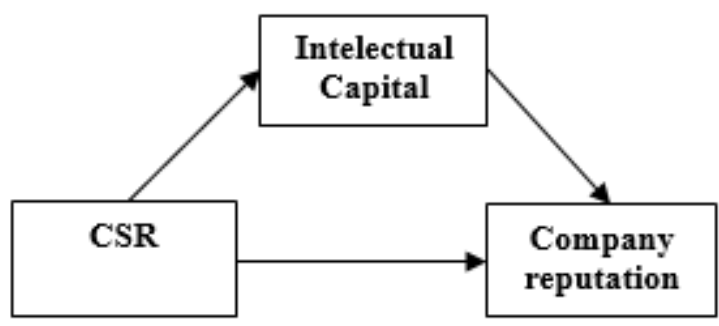

Fig. 1. Conceptual framework

\section{METHODS}

The method used in this research is descriptive method using a quantitative approach. The population used in this study is the annual reports of banking sector companies listed on the Indonesia Stock Exchange. The researcher used purposive sampling method in this study. The criteria taken in this study are:

- Banking companies listed on the Indonesia Stock Exchange prior to the research period

- The company was not delisted from the Indonesia Stock Exchange during the research period

- A bank that is neither a subsidiary company of an existing bank nor is it under Bank Indonesia maintenance. 
Based on these criteria, the samples used in this study were the financial reports of 41 companies in the 2016-2018 banking sector, so the samples used were123 financial reports.

To analyze the Data, the researchers used Partial Lease Square (PLS) with the PLS warp application. The variables used in this study are as follows:

Company reputation, use total shareholders return as a proxy. Corporate Social Responsibility disclosure is measured by the index number of the Corporate Social Responsibility Disclosure Index (CSRDI), the result of content analysis, based on the GRI (Global Reporting Initiatives) -G4 indicator which consists of 91 items., Intellectual capital Intellectual capital is a series of knowledge resources using component of VAICTM from the company's resources, namely physical capital (VACA - Value Added Capital Employed), human capital (VAHU Value Added Human Capital), and structural capital (STVA Structural Capital Value).

\section{RESULTS}

\section{A. Fit Test Model}

Test results Fit Indices Model explain that P-value both indices show results below 0.05 , which means they meet the APC and ARS criteria. AVIF also shows an index below 5. These results indicate that the model has fit with the data so that it can continue the next test.

\section{B. Convergent Validity}

Based on the results the output on Combined Loadings And Cross-Loadings stated that the factor value loading $>0.7$ (brackets and bolded values) for each manifest variable of all good constructs of CSR, intellectual capital, and company reputation, the $\mathrm{p}$ value also shows significant, namely $<0.05$. $>$ Likewise for the AVE value shown in Latent Variable Coefiicient with a value> 0.05.> This matter indicates that the requirements for convergent validity have been met, meaning that each manifest variable of all constructs is highly correlated.

\section{Discriminant Validity}

Based on the results Latent Variable Correlations output indicates that the root value of AVE is 1,000 greater than the correlation between latent variables, meaning that the discriminant validity requirements have been met, meaning that the different manifest variables of the construct are not highly correlated.

\section{Composite Reliability}

Based on the Latent Variable Coefficient, it shows that the value of composite reliability and Cronbach's alpha> 0.07 . This means that the measuring instrument used is accurate in making measurements.

\section{E. Test Inner Model}

1) R-squared: Based on Latent Variable Coefiicients score $\mathrm{R}$-squared for the company reputation variable of 0.216 means variable intellectual capital influenced by the CSR variable of $21.6 \%$. Latent Variable Coefiicients also shows that the value $\mathrm{R}$-squared for variables CSR to 0.575 means that the company's reputation variable is influenced by the CSR variable and intellectual capital amounted to $65.3 \%$.

2) $Q$-squared: Latent Variable Coefiicients shows value Q-square in this research model is greater than 0 , namely 0.196 and 0.586 , so it means that the research model has good predictive validity.

\section{F. Hypothesis Test}

1) Direct effect: Based on Path Coefiicients and P-values (Path Coefiicients) the direct relationship between variables is as follows:

- CSR has a positive and significant effect on intellectual capital, because the path value is 0.465 and $\mathrm{P}$-values $<0.0010 .05$, which means significant.

- CSR has a positive and significant effect on the company's reputation, because the path value is 0.718 and P-values $<0.0010 .05$, which means significant

- Intellectual capital has a positive and significant effect on the company's reputation, because the path value is 0.384 and P-values <0.001 0.05 which means significant.

2) Indirect effect: Based on Indirect Effect and P-values (Indirect Effect) the result of the indirect relationship is that CSR has a negative effect on the company's reputation indirectly and through intellectual capital is equal to -0.178 with p-values $0.001<0.05$ which means significant.

\section{G. Mediation Effect Test}

Based on the results of the study, it shows the path value for the direct relationship of the effect of CSR on company reputation equal to 0.77 and significant with $\mathrm{p}$ value $<0.01$. Furthermore, when testing the indirect effect with intellectual capital as a mediating variable shows the value of the CSR path at company reputation decreased to 0.75 and remained significant with a $\mathrm{p}$ value $<0.01$. With the results of testing the effect of the mediation, it shows that the form of mediation from intellectual capital on the effect of CSR on company reputation is partial mediation.

\section{DISCUSSION}

\section{A. The Effect of CSR on Intellectual Capital}

The results showed that CSR has a positive and significant effect on intellectual capital. This means that the higher the banking sector company discloses CSR, the higher the company's intellectual level, and vice versa, the higher the banking sector company discloses CSR, the higher the 
company's intellectual level. Based on the processed data, it shows that the CSR of banking sector companies has a tendency to increase so that the intellectual level of the company tends to be high, this is because banking sector companies tend to often carry out CSR programs, one of which is by providing training to employees, as it is known that banking is a financial institution that provides services. especially financial transactions, so it requires high trust from the public, therefore the banking sector must have employees with sufficient intellectual capital.

According to Perrini et al. [12], it is explained that in the human capital dimension, CSR can improve employee welfare. Furthermore, CSR can also improve companies and employees by increasing loyalty and motivation. The positive impact of CSR on the dimensions of organizational capital related to corporate strategy and culture can help the company's management process. Furthermore, the dimensions of relational capital consist of brand, customer and supplier image and finance where CSR results in the acquisition of new clients, increased company reputation and financial-related investor attention.

\section{B. The Effect of CSR on Company Reputation}

The results showed that CSR has a positive and significant effect on company reputation it means that the higher the CSR disclosure made by a banking sector company, the higher the reputation of a company, and vice versa, the lower the CSR disclosure made by a company, the lower the reputation of a company. Based on the processed data, it shows that the CSR of banking sector companies has a tendency to increase and the reputation of the banking sector companies tends to increase. This is in accordance with the signaling theory which explains that companies, especially the banking sector, are trying to disclose information that according to management is very important and of interest to investors and shareholders. where this information is good news for investors in making decisions. That is the banking sector companies have the function of collecting funds from the public so it is important to attract investors. This is in order to the funds that have been collected can be returned to the public in the form of credit. Even though CSR disclosure based on the GRI G-4 index is a self-assessment, banking sector companies feel the need to disclose CSR not only for the sake of fulfilling the obligations of the Financial Services Authority, but by disclosing CSR, banking sector companies hope to give a signal as good news for investors and shareholders to enhance the company's reputation.

The results of Park [3] show that CSR has a significant positive effect on the Company's reputation, while Purva Grover et al. Whose research entitled Impact of Corporate Social Responsibility on Reputation Insight From Tweets on Sustainable Development Goals By CEOS shows that CSR has a significant positive effect on the company's reputation. Coupled with research Maden et al. [6] which shows the results of CSR research have a significant positive effect on the company's reputation. Likewise, the research results González-
Ramos et al., Y ang et al., and Maden et al., ŠontaitePetkevičienè [4-6,18].

\section{The Effect of Intellectual Capital on Company Reputation}

The results showed that Intellectual capital has a positive and significant influence on the company's reputation. It means, the higher the intellectual capital level of companies in the banking sector, the higher the reputation of the company, and vice versa, the lower the intellectual capital level of companies in the banking sector, the lower the company's reputation. Based on the processed data shows that intellectual capital banking sector companies have an upward trend company reputation tends to be high. This shows that banking sector companies, in this case, are compatible with signaling theory to provide positive signals for investors and shareholders. This indicates that banking sector companies realize that disclosure of financial statements not only provides positive signals through company performance, but also needs to provide internal information companies in the form of intangible assets through disclosure of intellectual capital that cannot be disclosed in the financial statements, wherein intangible assets, especially intellectual capital, cannot be included in the financial statements due to problems with identification, recognition and measurement.

Chen et al. [21] explained that investors will give a higher value to companies that have higher intellectual resources than companies that have low intellectual resources. The value that an investor gives to the company will be reflected in the company's share price.

The results of this study are supported by OlmedoCifuentes and Martínez-León [11], Hannon [19], Friedman [20] and Özer and Çam [22] which show that human capital has a positive effect on stock prices. Human capital is considered a relevant value in making business appraisal decisions and as a result management must make the right resources in planning compensation policy to maximize the company's long-term competitiveness in the global market and also to create and manage human assets more effectively and efficiently. This shows that increasing intellectual capital can improve the company's reputation.

\section{Intellectual Capital Mediates CSR on Company Reputation}

The results showed that the mediating form of intellectual capital on the effect of CSR on company reputation is partial mediation (partial mediation) This shows that Intellectual Capital is not the only variable that can mediate the relationship between CSR and company reputation, meaning that there are other variables that are stronger to mediate the relationship between CSR and company reputation. This shows that CSR, accompanied by intellectual capital, cannot improve the company's reputation.

This is not in accordance with the opinion of Hijriah et al. [23] which explains that intellectual capital can strengthen CSR and market added value. This is because intellectual capital is 
a strategic asset for the sustainability and excellence of the company.

\section{CONCLUSION}

Based on data analysis, it can be concluded that CSR has a positive and significant effect on intellectual capital, CSR has a positive and significant effect on company reputation, intellectual capital has a positive and significant impact on company reputation, and intellectual capital can be a partial mediation variable among the CSR influence and the company reputation.

\section{ACKNOWLEDGMENT}

This study was supported by research Accounting Department STIE PGRI Dewantara Jombang. Thanks to reviewers for the comments and suggestions given. Thank you to all those who contributed to this research.

\section{REFERENCES}

[1] M. Sarstedt, P. Wilczynski, and T.C. Melewar, "Measuring reputation in global markets-A comparison of reputation measures' convergent and criterion validities," J. World Bus., 2013.

[2] G.M. De Castro, J.E.N. López, and P.L. Sáez, "Business and social reputation: Exploring the concept and main dimensions of corporate reputation,” J. Bus. Ethics, 2006, doi: 10.1007/s10551-005-3244-z.

[3] E. Park, "Corporate social responsibility as a determinant of corporate reputation in the airline industry," J. Retail. Consum. Serv., vol. 47, no. November 2018, pp. 215-221, 2019.

[4] M.I. González-Ramos, M.J. Donate, and F. Guadamillas, "The Effect of Technological Posture and Corporate Social Responsibility on Financial Performance Through Corporate Reputation,” Int. J. Innov., vol. 6, no. 2, pp. 164-179, 2018.

[5] L. Yang, Z. Yaacob, and S.Y. Teh, "Does reputation mediate the relationship between corporate social responsibility and performance of SMEs in China," Int. J. Econ. Manag., vol. 11, no. 2, pp. 335-354, 2017.

[6] C. Maden, E. Arıkan, E.E. Telci, and D. Kantur, "Linking Corporate Social Responsibility to Corporate Reputation: A Study on Understanding Behavioral Consequences," Procedia - Soc. Behav. Sci., 2012.

[7] Y. Yoon, Z. Gürhan-Canli, and N. Schwarz, "The effect of Corporate Social Responsibility (CSR) activities on companies with bad reputations,” J. Consum. Psychol., 2006.
[8] T. Bartley, "Institutional emergence in an era of globalization: The rise of transnational private regulation of labor and environmental conditions," Am. J. Sociol., 2007.

[9] Coop News, "How do UK supermarkets do corporate social responsibility?," vol. 31, no. 2, pp. 383-396, 2015.

[10] E. Passetti, A. Tenucci, L. Cinquini, and M. Frey, "M P RA Munich Personal RePEc Archive Intellectual capital communication: evidence from social and sustainability reporting," no. 16589, pp. 0-29, 2009.

[11] I. Olmedo-Cifuentes and I. Martínez-León, "Human Capital and Creation of Reputation and Financial Performance," Electron. J. Knowl. Manag., vol. 13, no. 3, pp. 209-218, 2008

[12] F. Perrini, A. Russo, and A. Tencati, "Perrini - 2007 - CSR strategies for SMEs and large firms.pdf," Journal of Business Ethics. 2007.

[13] D. Gallardo-Vázquez, M.J. Barroso-Méndez, M.L. Pajuelo-Moreno, and J. Sánchez-Meca, "Corporate social responsibility disclosure and performance: A meta-analytic approach," Sustain., vol. 11, no. 4, pp. 1 33, 2019.

[14] N. Marchyta and H. Semuel, "The Effect of Corporate Social Responsibility on Financial Performance of Banks in Indonesia: The Role of Intellectual Capital and Bankruption Risk,” Int. J. Psychosoc. Rehabil., 2020.

[15] M. Heinberg, H.E. Ozkaya, and M. Taube, "Do corporate image and reputation drive brand equity in India and China? - Similarities and differences,” J. Bus. Res., 2018.

[16] M.C. Branco and L.L. Rodrigues, "Communication of corporate social responsibility by Portuguese banks: A legitimacy theory perspective," Corp. Commun., vol. 11, no. 3, pp. 232-248, 2006.

[17] D.S. Dhaliwal, O.Z. Li, A. Tsang, and Y.G. Yang, "Voluntary nonfinancial disclosure and the cost of equity capital: The initiation of corporate social responsibility reporting," Account. Rev., 2011.

[18] M. Šontaitė-Petkevičienè, "CSR Reasons, Practices and Impact to Corporate Reputation,” Procedia - Soc. Behav. Sci., vol. 213, pp. 503508, 2015.

[19] J.M. Hannon, "Human Resource Reputation : Looking Good May Feel Good But Does It Add Value? W ORKING P APER S ERIES Human Resource Reputation: Looking Good May Feel Good But Does It Add Value?," no. July, 1995.

[20] B.A. Friedman, "Human resource management role implications for corporate reputation," Corp. Reput. Rev., 2009,.

[21] M.C. Chen, S.J. Cheng, and Y. Hwang, "An empirical investigation of the relationship between intellectual capital and firms' market value and financial performance,” J. Intellect. Cap., 2005.

[22] G. Özer and İ. Cam, "The Role of Human Capital in Firm Valuation: An Application on BIST," Procedia - Soc. Behav. Sci., 2016.

[23] A. Hijriah, B. Subroto, and N. Nurkholis, "Penguatan Pengungkapan Corporate Social Responsibility Dan Market Value Added Melalui Modal Intelektual," J. Akunt. Multiparadigma, vol. 10, no. 2, pp. 295 $307,2019$. 